founded in 1824 , it is as nearly as possible six months older than I am. It is something astounding to know what progress has been made since that time. I happened to take up to-day the syllabus of your sessional work here, and I turn, not unnaturally, to the class of Practical Physiology and Histology, and, on looking over the various doings of this course of instruction, it struck me that, thirty years ago, when I began my medical studies, there certainly was nobody in London-nay, nobody in the world-who could have given you this course of instruction. We had not the instruments which are requisite to carry it out. The whole course of medical study since that time has been completely changed-by, in the first place, discoveries made by the use of the microscope, and, in the scond place, by that application of delicate instruments to the illustration of the mechanism of the body, which is the very essence and a great part of modern physiology. At that time, even organic chemistry was hardly in existence. We used to use, when I was a student, what was called Turner's Chemistry. It is this recognition of the fact, that the study of life is essentially a question of applied physics and chemistry. That is what has changed the whole course of our medical studies. It is that which makes that elaborate appliance necessary, and that you who commence your medical studies should come prepared with the outlines of physics and chemistry as your foundations. One of the greatest reasons of the backwardness in medical study is, that those who come to study are, by reason of the lamentable defects of their common school education, utterly unprovided with a knowledge of what those physical studies mean.

I do not think it would be needful for me to detain you longer. The subject is a tempting one, and I might be disposed to enlarge still more upon the advantages which you who are now commencing your career have over those who are thirty or forty years older than yourselves. Though not enlarging upon these advantages at still greater length, if it were possible that I could stamp upon your minds as firmily and as strongly as it is burnt into my own, that all these appliances, and all these mechanical aids for the study of medicine, are simply thrown away unless they have the foundation of human hard work and clear-headedness to go upon. You have before you probably that which is the most responsible of all human careers. It is hard for you not to realise that. It is hard for you, curbing the hot blood of youth, to understand what issues may depend upon your present career; but depend upon it, exactly in proportion as you make use of these advantages, as you feel the burden of your responsibilities, as you acquire that knowledge which was essential for you, so will your lives in the future be passed in the satisfaction of well merited renown, or in the misery of a violated con science.

\section{A CASE OF POISONING BY MUSHROOMS.}

\section{By James Sedgwick, M.R.C.S., Boroughbridge.}

THE following case of poisoning by mushrooms appears sufficiently severe, and probably rare, in the early advent of tetanic muscular spasm, as to demand a short notice from me, more especially as such symptoms, I find, have only been very seldom seen, and then in fatal cases.

About 6.15 P.M. one day in August 1874, T. F., when in perfect health, partook of about eight or ten carefully chosen small young mushrooms; after which, he took a walk round his farm, retired to bed about I I P.M., feeling perfectly well, and not in the slightest degree suspicious that the mushrooms could be poisonous, and entirely ignorant of any of the symptoms of poisoning by fungi.

About I. 30 A.M., when I first saw my patient, I found him supported by his nurses, walking in the open air. He said he felt so sleepy, and had been obliged to leave his bed and room, because he could only breathe with very great difficulty. He added that, after sleeping until 12.15, he awoke suddenly with spasmodic twitching in his hands and arms, soon followed by a suffocative feeling; so much so, that he felt he should die from it. This necessitated his removal to the open air ; and a glass of brandy and water was given.

At I.30 A.M., he was drowsy, and not quite collected; said he felt as if he should soon be delirous; but both tetanic muscular spasm and dyspnœa had subsided. Pupils somewhat inactive; pulse regular. I at once emptied the stomach twice by emetics, and then gave an aperient. The vomited matter contained several mushrooms, very probably all that had been taken; and, though six hours had elapsed since the meal of mushrooms had been eaten, very little could have passed the stomach. Great relief followed the action of the emetics. He had no return of discomfort, except a feeble digestion, and for a few days a feeling in his arms which he described as similar to that caused by riding an unruly pulling horse for a day.

\section{R E P O R T \\ OF THE \\ COMMITTEE OF THE BRITISH MEDICAL ASSOCIATION TO INVESTIGATE THE ANTAGONISM OF MEDICINES.}

\author{
By JOHN HUGHES BENNETT, M.D., F.R.S.E., \\ Chairman and Reporter.

\section{II.-Antagonism between Sulphate of Atropia and} \\ Calabar Bean.
}

WHEN the Committee commenced their investigations into this subject, the antagonism had already been indicated by Dr. Fraser. It was resolved, however, to determine the question with exactitude. Subsequently, a very lengthened inquiry was published by Dr. Fraser, * with whose general results those of the Committee coincide.

The preparation of Calabar bean employed was in the form of an alcoholic extract made by Dr. Cook, formerly of the firm of Messrs. T. and H. Smith of Edinburgh, now residing in Liverpool. It was prepared as follows. The powdered beans were acted upon with spirit of specific gravity .830 , at $60 \mathrm{deg}$. Fahr., until the powder was exhausted. The clear solution thus obtained was evaporated in a vacuum of twenty-six inches until the spirit was entirely removed. To the residue thus prepared, three ounces of water were added, and the whole was heated gently. Tine residue was partly dissolved, leaving some oily matter floating on the surface. This mixture was filtered, and a fluid obtained, one ounce of which represented four ounces and a half of Calabar bean; or, in other words, twenty eight grains of the extract free from oil were present in each ounce.

Numerous experiments were made on rabbits and on rats.

\section{A. Experiments on Rabbits.}

TABLE IX.-Showing Effects of a Minimum Fatal Dose of the Extract of Calubar Bean on Rabbits.

\begin{tabular}{|c|c|c|c|}
\hline No. & $\begin{array}{l}\text { Weight of } \\
\text { Rabbit. }\end{array}$ & $\begin{array}{l}\text { Dose of } \\
\text { grains. }\end{array}$ & Result. \\
\hline $\begin{array}{l}116 \\
117 \\
118 \\
119 \\
120 \\
121 \\
122 \\
123 \\
124 \\
125 \\
126 \\
127\end{array}$ & $\begin{array}{l}3 \text { lbs. } 8 \mathrm{oz} . \\
3 \text { lbs. } 8 \mathrm{oz} . \\
3 \text { lbs. } 12 \mathrm{oz} . \\
3 \text { lbs. } 12 \mathrm{oz} . \\
4 \text { lbs. } \\
4 \text { lbs. } 1 \mathrm{oz} . \\
4 \text { lbs. } 2 \mathrm{oz} . \\
4 \text { lbs. } 4 \mathrm{oz} . \\
3 \text { lbs. } 6 \mathrm{oz} . \\
4 \text { lbs. } \\
3 \text { lbs. } 8 \mathrm{oz} . \\
3 \text { lbs. } 7 \frac{1}{2} \mathrm{oz} .\end{array}$ & $\begin{array}{c}\frac{1}{4} \\
\frac{1}{2} \\
\frac{1}{2} \\
1 \frac{1}{2} \\
\frac{1}{2} \\
1 \\
1 \frac{1}{3} \\
\frac{1}{4} \\
\frac{3}{4} \\
\frac{3}{4} \\
\frac{1}{2} \\
\frac{3}{4} \\
\frac{1}{2}\end{array}$ & $\begin{array}{l}\text { Died in } 1 \text { hour } 40 \text { minutes } \\
\text { Died in } 12 \text { minutes } \\
\text { Recovered; ill nearly } 24 \text { hours } \\
\text { Died in } 7 \text { minutes } \\
\text { Died in } 19 \text { minutes } \\
\text { Died in } 8 \text { minutes } \\
\text { Recovered; very ill } 6 \text { hours } \\
\text { Died in } 6 \text { minutes } \\
\text { Died in } 29 \text { minutes } \\
\text { Recovered after severe illness } \\
\text { Died in } 31 \text { minutes } \\
\text { Recovered after severe illness }\end{array}$ \\
\hline
\end{tabular}

Taking into account the relative weights of these rabbits, it was concluded that three-quarters of a grain of extract of Calabar bean for every three pounds weight of rabbit was the minimum fatal dose of the extract employed; and it is so understood in all the investigations on the supposed antagonistic properties of other substances to Calabar bean. The minimum fatal dose of the extract prepared by Dr. Fraser was $\mathbf{r} .2$ grains for every three pounds weight of animal; but he states (p. 575) "that the lethal activity of this extract" [the extract given him by Dr. Cook] " is considerably greater than that of the extract prepared by myself".

The symptoms following the subcutaneous injection of three-quarters of a grain of this extract into a rabbit were as follows.

Experiment 1 26.-Male rabbit, weighing 3 lbs. 8 ounces. Threefourths of a grain of extract of Calabar bean, dissolved in ten minims of water, were injected under the skin of the back. In a minute and a half, there were slight twitchings of the skin. In three minutes, the breathing became very hurried, and the animal seemed to be distressed. Saliva now accumulated profusely in the mouth. In two minutes more, the animal rested on its abdomen and chest, and spread out its legs, which were stiff. It attempted to regain its natural posi-

* Proceedings of the Royal Socicty of Edinburgh, $1868-69$, pp. 587-59o. See also the Practitioner for February 1870 ; and an elaborate paper in the Transactions of the Royal Society of Edinburgh, vol, xxvi, part iii, for the session $1870-7$ I. 